\title{
Estimation of power generation in a thermal oil heater by a new material based thermoelectric generator
}

\author{
M. Riaz, M. C. Barma, R. Saidur \& B. D. Long \\ Department of Mechanical Engineering, Faculty of Engineering, \\ University of Malaya, Malaysia
}

\begin{abstract}
During the last three decades, there has been growing interest in applying thermoelectric technology to improve the efficiency of waste heat recovery .This study reports an estimation of the amount of power produced by a thermoelectric generator (TEG) placed between the flue gas duct and fresh air duct of an industrial thermal oil heater to recover waste heat. A plate fin heat sink is used to transfer the heat from flue gas to the thermoelectric generator. The effects of various design parameters and flow parameters were investigated in order to maximize the power generation. Then the best suited conditions were applied to new a thermoelectric generator module based on recently developed $\mathrm{Bi}_{2} \mathrm{Te}_{3}, \mathrm{PbTe}$ and TAGS thermoelectric group materials. A thermoelectric generator based on p-type $(\mathrm{Bi}, \mathrm{Sb})_{2} \mathrm{Te}_{3}$ and n-type hot forged $\mathrm{Bi}_{2} \mathrm{Te}_{3}$ generates $4.4 \mathrm{~W}$, which is about $19 \%$ improvement in output power compared to a commercial module (HZ-2). For a proposed system, in a biomass fired thermal oil heater, the estimated annual power generation could be around 181,209 $\mathrm{kWh}$. The thermal efficiency of the TEG modules based on recently developed thermoelectric materials could be enhanced by up to $8.18 \%$. The specifications of plate fin heat sinks as well as thermoelectric properties of the $\mathrm{p}-\mathrm{n}$ materials of the system have a substantial impact on the performance of the TEG module.

Keywords: waste heat recovery, thermoelectric generator, renewable energy, thermoelectric material.
\end{abstract}




\section{Introduction}

Thermoelectric (TE) generator is a new type of environmentally friendly energy conversion technology. A thermoelectric generator has no moving parts and is compact, quiet, highly reliable and environmentally friendly. Due to these pros it becomes a promising research area. The primary challenge is its relatively low heat to electricity conversion efficiency. The relatively low conversion efficiency of thermoelectric modules $(\sim 5 \%)$ hinders the growth of their applications. But low efficiency problem is not the major issue when TEG is used for waste heat recovery because of the costless thermal energy input [1]. Thermoelectric generators (TEG) generate electrical power from heat energy by using Seebeck effect, Peltier effect, Thomson effect. These effects are accompanied by other factors such as Fourier heat conduction laws and Joule heating [2]. A thermoelectric generator will be efficient if it could satisfy the following criteria. (1) low thermal conductivity $(\kappa)$, which confirms large temperature difference between both ends of the material, (2) high electrical conductivity $(\sigma)$, which confirms the reduction of internal resistance of the material, and (3) large thermo electromotive force (Seebeck coefficient, $\alpha$ ), which is required to obtain a high voltage [3].

Approximately $60 \%$ energy is wasted from different sources without practical application [3]. TEG modules can be exploited to harvest waste heat from automobile exhaust [4-8] to industrial operations such as biomass boiler [9], small scale pellet boiler [10], cement plants, marine waste incinerator [11], refineries, glass manufacturing, foundries and other heated components like Wood burning stoves [12], geothermal, solar salt ponds, solar concentrators [13].

The efficiency of the thermoelectric generator is dependent on module properties as well as system configuration. This paper represents the effect of changing module properties on output power. This model can be used to evaluate the performance of newly developed TE materials. In this study, the materials are selected according to the temperature range of the flue gas of biomass fired $\mathrm{TOH}$.

\section{Mathematical modelling}

Thermoelectric generators work on temperature differentials using the Seebeck effect. The greater the temperature differential (DT) between hot and cold side of the TEG module, the greater the amount of power will produce. Figure 1 shows the working principle of TEG.

Supply heat to the hot side $\left(\mathrm{Q}_{\mathrm{H}}\right)$ and removal heat from the cold side $\left(\mathrm{Q}_{\mathrm{C}}\right)$ of the thermoelectric module can be expressed by Eqn. (1) and Eqn. (2) respectively

$$
\begin{gathered}
Q_{C}=\alpha I T_{L}+K\left(T_{H}-T_{L}\right)+1 / 2 I^{2} R_{G} \\
\mathrm{Q}_{\mathrm{H}}=\alpha \mathrm{IT}_{\mathrm{H}}+\mathrm{K}\left(\mathrm{T}_{\mathrm{H}}-\mathrm{T}_{\mathrm{L}}\right)-1 / 2 \mathrm{I}^{2} \mathrm{R}_{\mathrm{G}}
\end{gathered}
$$




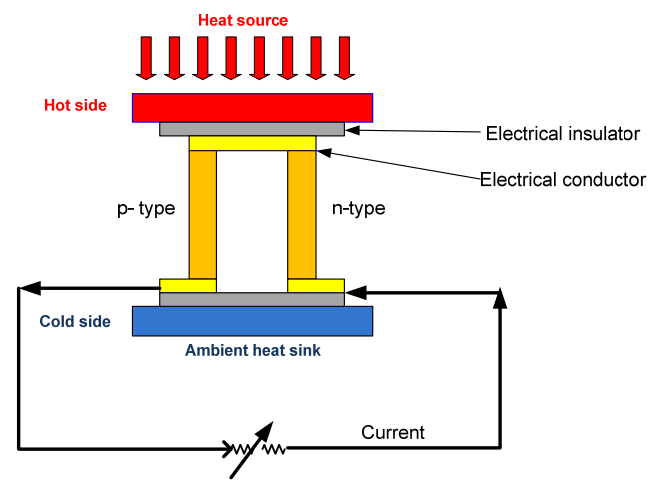

Figure 1: Schematic of a working TEG.

\subsection{Thermoelectric properties of TEG module}

Thermoelectric properties of recently developed new TE materials are presented in Table 1.

Table 1: Thermoelectric properties of new TE materials.

\begin{tabular}{|c|c|c|c|c|c|c|}
\hline $\begin{array}{l}\text { Group of } \\
\text { materials }\end{array}$ & Compound & $\begin{array}{l}\text { Resistivity } \\
(\mu \Omega \mathrm{m})\end{array}$ & $\begin{array}{l}\text { Conductivity } \\
(\mathrm{W} / \mathrm{mK})\end{array}$ & $\begin{array}{c}\text { Seebeck } \\
\text { co-efficient } \\
\mu \mathrm{V} / \mathrm{K}\end{array}$ & $\mathrm{ZT}$ & Ref \\
\hline \multirow{4}{*}{$\mathrm{Bi}_{2} \mathrm{Te}_{3}$} & Nano Composite $\mathrm{Bi}_{2} \mathrm{Te}_{3}$ & 12.2 & 0.75 & 150 & 1.00 & [14] \\
\hline & $\mathrm{Bi}_{2} \mathrm{Te}_{3} / \mathrm{Sb}_{2} \mathrm{Te}_{3}$ & 12.5 & 0.75 & 180 & 1.40 & [15] \\
\hline & Hot forged $\mathrm{Bi}_{2} \mathrm{Te}_{3}$ & 8.50 & 1.12 & 160 & 1.18 & [16] \\
\hline & $\begin{array}{c}\mathrm{Bi}_{2} \mathrm{Se}_{0.3} \mathrm{Te}_{2.7}+\mathrm{x} \text { vol. } \% \gamma- \\
\mathrm{Al}_{2} \mathrm{O}_{3}\end{array}$ & 9.43 & 1.10 & 157 & 0.98 & [17] \\
\hline \multirow{4}{*}{$\mathrm{PbTe}$} & $0.03 \mathrm{~mol}_{0} \mathrm{PbI}_{2}, \mathrm{PbTe}$ & 10.00 & 1.00 & 220 & 1.55 & [18] \\
\hline & $(\mathrm{PbTe})_{0.88}(\mathrm{PbS})_{0.12}$ & 40.00 & 0.75 & 245 & 0.86 & [19] \\
\hline & $\mathrm{PbTe}: \mathrm{La} / \mathrm{Ag}_{2} \mathrm{Te}$ & 24.00 & 1.08 & 190 & 0.60 & [20] \\
\hline & $\begin{array}{l}\text { La-doped }(\mathrm{PbTe})_{0.945} \\
\quad\left(\mathrm{Ag}_{2} \mathrm{Te}\right)_{0.055}\end{array}$ & 32.5 & 1.05 & 140 & 0.27 & [20] \\
\hline \multirow{3}{*}{ TAGS } & $\begin{array}{l}\mathrm{Ag}_{6.52} \mathrm{Sb}_{6.52} \mathrm{Ge}_{35.96} \mathrm{Te}_{50} \mathrm{Dy}_{1} \\
\text { (TAGS-85+1\% Dy for Ge) }\end{array}$ & 7.00 & 1.40 & 138 & 0.70 & [21] \\
\hline & $\begin{array}{c}\mathrm{Ag}_{6.52} \mathrm{Sb}_{6.52} \mathrm{Ge}_{34.96} \mathrm{Te}_{50} \mathrm{Dy}_{2} \\
\text { (TAGS- } 85+2 \% \text { Dy for Ge) }\end{array}$ & 9.15 & 1.70 & 144 & 0.70 & [21] \\
\hline & TAGS-75 & 17.90 & 1.20 & 204 & 0.80 & [22] \\
\hline
\end{tabular}




\subsection{Performance of TEG}

Power generation by TEG module depends on Seebeck coefficient $(\alpha)$, internal electrical resistance $\left(R_{G}\right)$ and thermal conductance $(K)$. Output power can be quantified in two ways, by multiplying output voltage and current or by subtracting removal heat from supply heat.

Output power can be obtained by using the following equation

$$
P_{O}=V_{O} I_{O}=Q_{H}-Q_{C}
$$

Inserting Eqn. (1) and Eqn. (2) into Eqn. (3), the output power can be written by the equation stated below

$$
P_{O}=\alpha I\left(T_{H}-T_{L}\right)-I^{2} R_{G}
$$

Again by combining Eqn. (3) and Eqn. (4), the output voltage can be expressed by the following equation

$$
V_{O}=P_{O} / I_{O}=\alpha\left(T_{H}-T_{L}\right)-I R_{G}
$$

If the condition of power generation is open circuit $(I=0)$, Eqn. (5) can be expressed by the equation given below

$$
V_{O}=\alpha\left(T_{H}-T_{L}\right)
$$

The Seebeck coefficient $(\alpha)$ can be written by the following equation

$$
\alpha=\frac{V_{O}}{\left(T_{H}-T_{L}\right)}
$$

The value of internal electrical resistance $\left(\mathrm{R}_{\mathrm{G}}\right)$ can be obtained by combining Eqn. (5) and Eqn. (7). Consequently, the value of thermal conductance (K) can be obtained by substituting $\alpha$ and $\mathrm{R}_{\mathrm{G}}$ into Eqn. (1). Taking the $1^{\text {st }}$ order partial derivatives of Eqn. (4) with respect to I and assuming the result on the left hand side of equation is zero [23], the output current $\mathrm{I}_{O}$ can be expressed by following equation

$$
I_{O}=\frac{\alpha\left(T_{H}-T_{L}\right)}{2 R_{G}}
$$

By using the Eqn. (9), the thermal efficiency of TEG can be obtained

$$
\eta_{G}=\frac{P_{O}}{Q_{H}}
$$




\subsection{Thermal resistance model of the waste heat recovery}

In this study, the source of heat is the high temperature flue gas of Thermal Oil Heater (TOH). Plate fin heat sink on the hot side of the TEG module is used to supply sufficient amount of heat and maintain high temperature on hot side. Plate fin heat sink on cold side is used to minimize the cold junction temperature by increasing the amount of removal heat from cold side. Thus plate fin heat sinks on both sides, make the temperature difference maximum between the junctions.

At the interface of two surfaces, thermal resistance can be expressed by the equation stated below

$$
R_{i}=\frac{t_{i}}{k_{i} A_{C}}
$$

The thermal resistance for the base of the plate fin heat sink can be written by the following equation

$$
R_{m}=\frac{t_{b}}{k_{b} A_{b}}=\frac{t_{b}}{k_{b}\left(W_{b} L_{b}\right)}
$$

According to the Newtons law of cooling, during heat transfer between fluid and solid surface a convectional thermal resistance $\left(R_{\text {conv }}\right)$ is arised. The value of $R_{\text {conv }}$ can be expressed by equation given below

$$
R_{\text {conv }}=\frac{1}{h A_{\text {eff }}}
$$

For plate fin heat sink effective heat transfer area and efficiency can be obtained by using Eqns. (13)-(15)

$$
\begin{gathered}
A_{\text {eff }}=\eta_{f} \times\left(2 N W H_{f}\right)+(N-1) b W \\
\eta_{f}=\frac{\tanh \left(m H_{f}\right)}{m H_{f}} \\
m=\sqrt{\frac{h p}{k_{f} t_{f}}}=\sqrt{\frac{h \times\left[2 \times\left(t_{f}+L\right)\right]}{k_{f}\left(t_{f} \times L\right)} \cong \sqrt{\frac{2 h}{k_{f} \times t_{f}}}}
\end{gathered}
$$

Thermal resistnce between two sides of the TEG module can be written by following equation

$$
R_{T E G}=\frac{T_{H}-T_{L}}{Q_{H}-Q_{C}}
$$


Overall thermal resistance and overall heat transfer coefficient can be obtained from the Eqns. (17), (18)

$$
\begin{gathered}
U_{H}=\frac{1}{R_{\text {overall }, H} A_{H}} \\
U_{C}=\frac{1}{R_{\text {overall }, L} A_{L}}
\end{gathered}
$$

The supply heat $\left(\mathrm{Q}_{\mathrm{H}}\right)$ to the hot junction and removal heat $\left(\mathrm{Q}_{\mathrm{C}}\right)$ from the cold junction can be expressed as following equations

$$
\begin{gathered}
Q_{H}=U_{H} A_{H}\left(T_{S}-T_{H}\right) \\
Q_{C}=U_{C} A_{L}\left(T_{L}-T_{C}\right)
\end{gathered}
$$

By combining Eqn. (1) with Eqn. (19) and Eqn. (2) with Eqn. (20), $\mathrm{T}_{\mathrm{H}}$ and $\mathrm{T}_{\mathrm{L}}$ can be expressed as equations given below

$$
\begin{gathered}
T_{H}=\frac{U_{H} A_{H} T_{S}+K T_{L}+\frac{1}{2} I^{2} R_{G}}{\alpha I+K+U_{H} A_{H}} \\
T_{L}=\frac{U_{C} A_{L} T_{C}+K T_{H}+\frac{1}{2} I^{2} R_{G}}{U_{C} A_{L}+K-\alpha I}
\end{gathered}
$$

The values of $T_{H}$ and $T_{L}$ are derived by the iterative method for different source temperatures and other variations. Consequently, $\mathrm{T}_{\mathrm{H}}, \mathrm{T}_{\mathrm{L}}, \alpha$ and $\mathrm{R}_{\mathrm{G}}$ are Substituted into Eqn. (8) to derive $\mathrm{I}_{\mathrm{O}}$. Then $\mathrm{T}_{\mathrm{H}}, \mathrm{T}_{\mathrm{L}}, \alpha, \mathrm{R}_{\mathrm{G}}, \mathrm{K}$ and $\mathrm{I}_{\mathrm{O}}$ are replaced into Eqns. (1), (2), (4) and Eqn. (5) to find out the values of $\mathrm{Q}_{\mathrm{H}}, \mathrm{Q}_{\mathrm{C}}, \mathrm{P}_{\text {out }}$ and $\mathrm{V}_{\text {out. }}$

\section{Schematic of TEG application}

The scope of waste heat recovery from a biomass fired Thermal oil heater has been investigated. The capacity of Thermal Oil Heater (TOH) is $14 \mathrm{MW}$. Average flue gas temperature was around $573 \mathrm{~K}$. The flue gas goes to the chimney through the ducts and before going to the chimney it passes through the air preheater (APH) and water preheater (WPH. To generate electricity from heat energy of moderately high temperature flue gas, TEG modules are proposed to place before APH and WPH on the flue gas duct. Plate fin heat sinks were used to enhance the performance of TEG. Hot side plate fin heat sink was in the flue gas duct and the cold side plate fin heat sink was in the fresh air duct. 
Recently developed materials with high figure of merit are chosen from different thermoelectric material groups. Dimensions of the duct where thermoelectric generator is placed is illustrated in Table 2 .

Table 2: System parameters.

\begin{tabular}{lcc}
\hline Parameter & Unit & Value \\
\hline Duct width & $\mathrm{m}$ & 2.3 \\
Duct height & $\mathrm{m}$ & 1.3 \\
Duct length & $\mathrm{m}$ & 2 \\
Number of TEG row & No & 33 \\
Number of module per row & No & 78 \\
\hline
\end{tabular}

Dimensions of plate fin heat sink are given in Table 3.

Table 3: Plate fin heat sink dimensions.

\begin{tabular}{llc}
\hline Parameter & Unit & Value \\
\hline Fin width & $\mathrm{mm}$ & 60 \\
Fin thickness & $\mathrm{mm}$ & 1.5 \\
Fin height & $\mathrm{mm}$ & 40 \\
Base width of heat sink(for 8 fin) & $\mathrm{mm}$ & 29.50 \\
Fin Spacing & $\mathrm{mm}$ & 2.50 \\
\hline
\end{tabular}

\section{Results and discussion}

Output power increases with the increment of temperature difference between two sides of the TEG module. Different ranges of output power have been identified from different combination of $p-n$ materials. The TE materials with higher figure of merit (ZT) are generating more power. Having higher figure of merit (ZT) of $\mathrm{p}$-n combinations, Bismuth telluride group based module is producing higher power and due to lower figure of merit (ZT), p-n combination of Lead telluride group and TAGS group based modules are generating lower power. The n-type nano composite $\mathrm{Bi}_{2} \mathrm{Te}_{3}$ and p-type $(\mathrm{Bi}, \mathrm{Sb})_{2} \mathrm{Te}_{3}$ gives the maximum peak output power $4.44 \mathrm{~W}$ and n-type La-doped $(\mathrm{PbTe})_{0.945}\left(\mathrm{Ag}_{2} \mathrm{Te}\right)_{0.055}$ and p-type $\mathrm{Ag}_{6.52} \mathrm{Sb}_{6.52} \mathrm{Ge}_{34.96} \mathrm{Te}_{50} \mathrm{Dy}_{2}$ gives minimum output power $1.58 \mathrm{~W}$. 


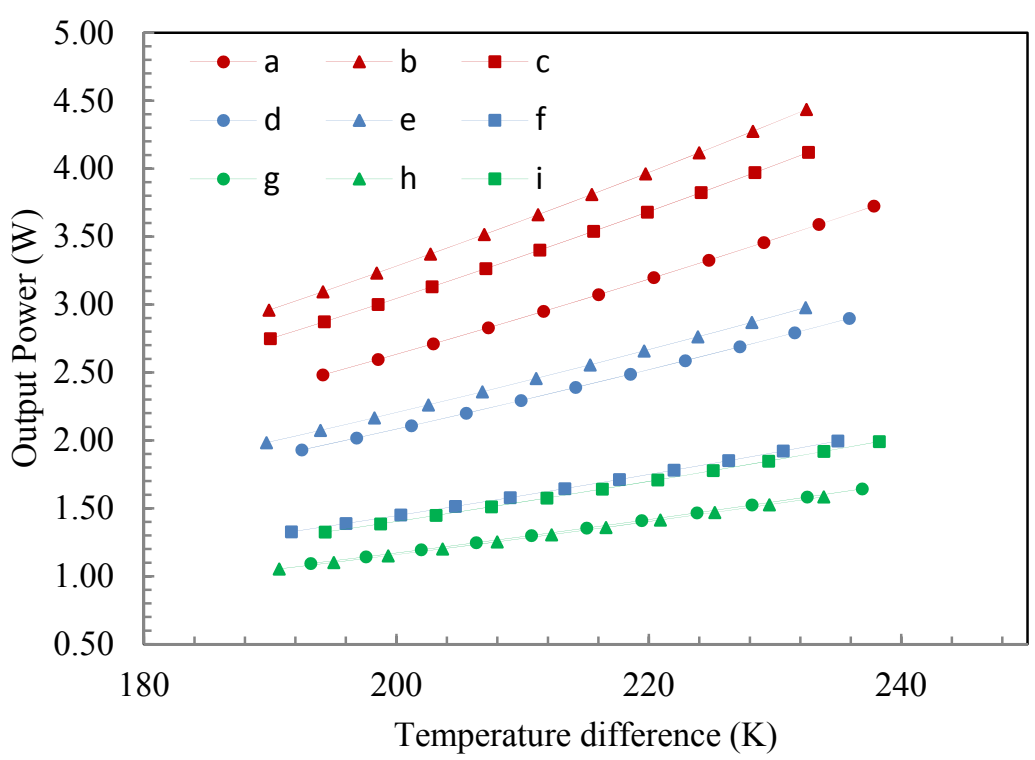

Figure 2: Effect of temperature diffence on output power of different module. $\left(\mathrm{a}=\mathrm{n}\right.$-type nano composite $\mathrm{Bi}_{2} \mathrm{Te}_{3}$ and p-type $(\mathrm{Bi}, \mathrm{Sb})_{2} \mathrm{Te}_{3}$, $\mathrm{b}=$ n-type hot forged $\mathrm{Bi}_{2} \mathrm{Te}_{3}$ and p-type $\left(\mathrm{Bi}, \mathrm{Sb}_{2}\right)_{2} \mathrm{Te}_{3}, \mathrm{c}=$ n-type $\mathrm{Bi}_{2} \mathrm{Se}_{0.3} \mathrm{Te}_{2.7}+\mathrm{x} \quad$ vol.\% $\quad \gamma-\mathrm{Al}_{2} \mathrm{O}_{3}$ and p-type $(\mathrm{Bi}, \mathrm{Sb})_{2} \mathrm{Te}_{3}$, $\mathrm{d}=$ n-type $(\mathrm{PbTe})_{0.88}(\mathrm{PbS})_{0.12}$ and p-type $0.03 \mathrm{~mol} \% \mathrm{PbI}_{2}, \mathrm{PbTe}$, $\mathrm{e}=$ n-type $\mathrm{PbTe}: \mathrm{La} / \mathrm{Ag}_{2} \mathrm{Te}$ and p-type $0.03 \mathrm{~mol} \% \mathrm{PbI}_{2}, \mathrm{PbTe}$, $\mathrm{f}=$ n-type La-doped $(\mathrm{PbTe})_{0.945}\left(\mathrm{Ag}_{2} \mathrm{Te}\right)_{0.055}$ and p-type 0.03 mol\% $\mathrm{PbI}_{2}, \quad \mathrm{PbTe}, \mathrm{g}=\mathrm{n}$-type La-doped $(\mathrm{PbTe})_{0.945}\left(\mathrm{Ag}_{2} \mathrm{Te}\right)_{0.055}$ and p-type $\mathrm{Ag}_{6.52} \mathrm{Sb}_{6.52} \mathrm{Ge}_{35.96} \mathrm{Te}_{50} \mathrm{Dy} 1, \mathrm{~h}=\mathrm{n}$-type La-doped $(\mathrm{PbTe})_{0.945}\left(\mathrm{Ag}_{2} \mathrm{Te}\right)_{0.055}$ and p-type $\mathrm{Ag}_{6.52} \mathrm{Sb}_{6.52} \mathrm{Ge}_{34.96} \mathrm{Te}_{50}$ Dy2, $\mathrm{i}=$ n-type La-doped $(\mathrm{PbTe})_{0.945}\left(\mathrm{Ag}_{2} \mathrm{Te}\right)_{0.055}$ and p-type TAGS-75).

Using Eqns. (4), (8), (21), (22) and taking thermoelectric properties of the materials from Table 1, variation of performance with hot side temperature has been obtained and shown in Figure 3. The output power increases with the rise of hot side temperature and the hot side temperature varies as flue gas temperature fluctuates. The flue gas temperature was varied from $523 \mathrm{~K}$ to $573 \mathrm{~K}$. When the hot side temperature increases, it directly enhances the temperature difference between hot and cold side of the TEG module. According to the Seebeck effect and from Eqns. (6) and (4), enhanced temperature difference improves the output voltage and hence output power. 


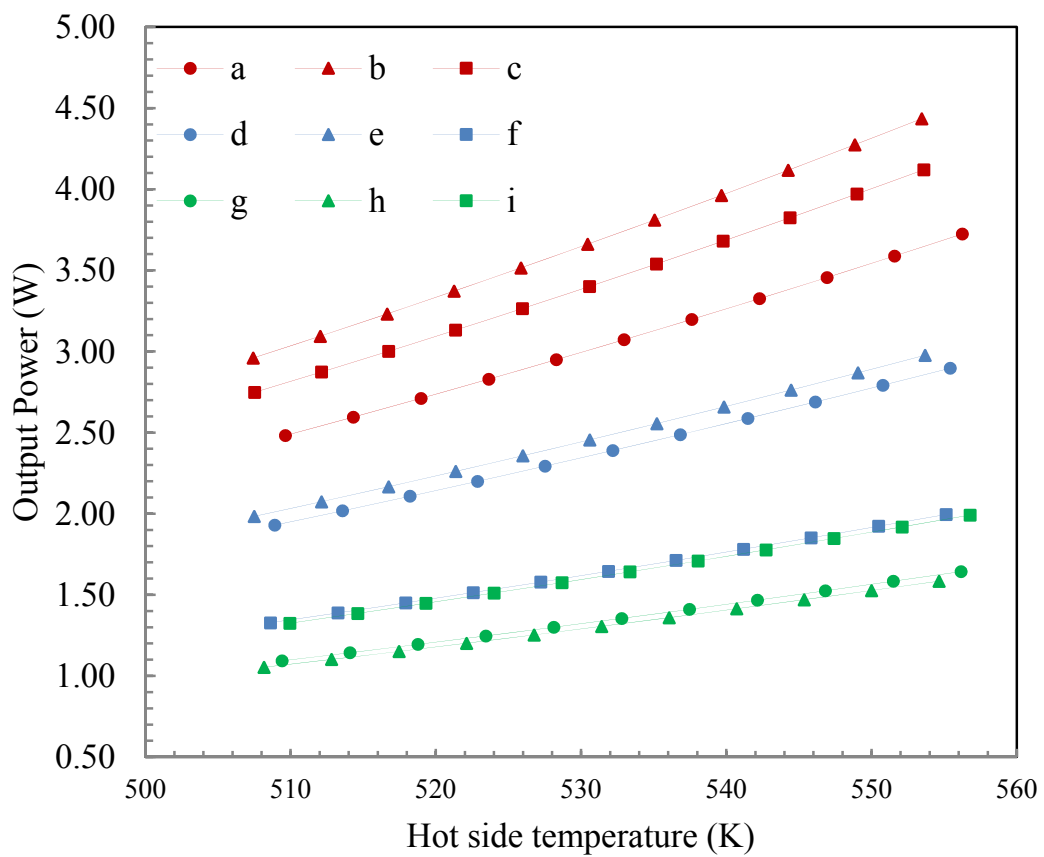

Figure 3: Effect of hot side temperature on power of different TE material. $\left(\mathrm{a}=\mathrm{n}\right.$-type nano composite $\mathrm{Bi}_{2} \mathrm{Te}_{3}$ and $\mathrm{p}$-type $(\mathrm{Bi}, \mathrm{Sb})_{2} \mathrm{Te}_{3}, \mathrm{~b}=\mathrm{n}$-type hot forged $\mathrm{Bi}_{2} \mathrm{Te}_{3}$ and p-type $\left(\mathrm{Bi}, \mathrm{Sb}_{2} \mathrm{Te}_{3}, \mathrm{c}=\right.$ n-type $\mathrm{Bi}_{2} \mathrm{Se}_{0.3} \mathrm{Te}_{2.7}+\mathrm{x}$ vol. $\% \gamma-\mathrm{Al}_{2} \mathrm{O}_{3}$ and -type $(\mathrm{Bi}, \mathrm{Sb})_{2} \mathrm{Te}_{3}, \mathrm{~d}=$ n-type $(\mathrm{PbTe})_{0.88}(\mathrm{PbS})_{0.12}$ and p-type $0.03 \mathrm{~mol} \% \mathrm{PbI}_{2}, \mathrm{PbTe}, \mathrm{e}=\mathrm{n}$-type $\mathrm{PbTe}: \mathrm{La} / \mathrm{Ag}_{2} \mathrm{Te}$ and p-type $0.03 \quad \mathrm{~mol}_{\%} \quad \mathrm{PbI}_{2}, \quad \mathrm{PbTe}, \mathrm{f}=\mathrm{n}$-type La-doped $(\mathrm{PbTe})_{0.945}\left(\mathrm{Ag}_{2} \mathrm{Te}\right)_{0.055}$ and p-type $0.03 \quad \mathrm{~mol}^{\%} \quad \mathrm{PbI}_{2}$, PbTe, $\quad \mathrm{g}=$ n-type La-doped(PbTe $)_{0.945}\left(\mathrm{Ag}_{2} \mathrm{Te}\right)_{0.055}$ and p-type $\quad \mathrm{Ag}_{6.52} \mathrm{Sb}_{6.52} \mathrm{Ge}_{35.96} \mathrm{Te}_{50} \mathrm{Dy} 1, \quad \mathrm{~h}=\mathrm{n}$-type La-doped $(\mathrm{PbTe})_{0.945}\left(\mathrm{Ag}_{2} \mathrm{Te}\right)_{0.055}$ and $\mathrm{p}$-type $\mathrm{Ag}_{6.52} \mathrm{Sb}_{6.52} \mathrm{Ge}_{34.96} \mathrm{Te}_{50} \mathrm{Dy} 2, \mathrm{i}=\mathrm{n}$ type La-doped $(\mathrm{PbTe})_{0.945}\left(\mathrm{Ag}_{2} \mathrm{Te}\right)_{0.055}$ and p-type TAGS-75).

By using Eqns. (3) and (9) the variation of output power with thermal efficiency has been calculated and plotted in Figure 4. The heat flow through the TEG module directly proportional to heat supplied to the hot side of the TEG module. According to the Fourier's law of conduction, thermal conductivity of the p-n block of the TEG module and the temperature difference between two sides is the determiner of heat flow through the TEG module as the other conditions are same for all material combinations. 


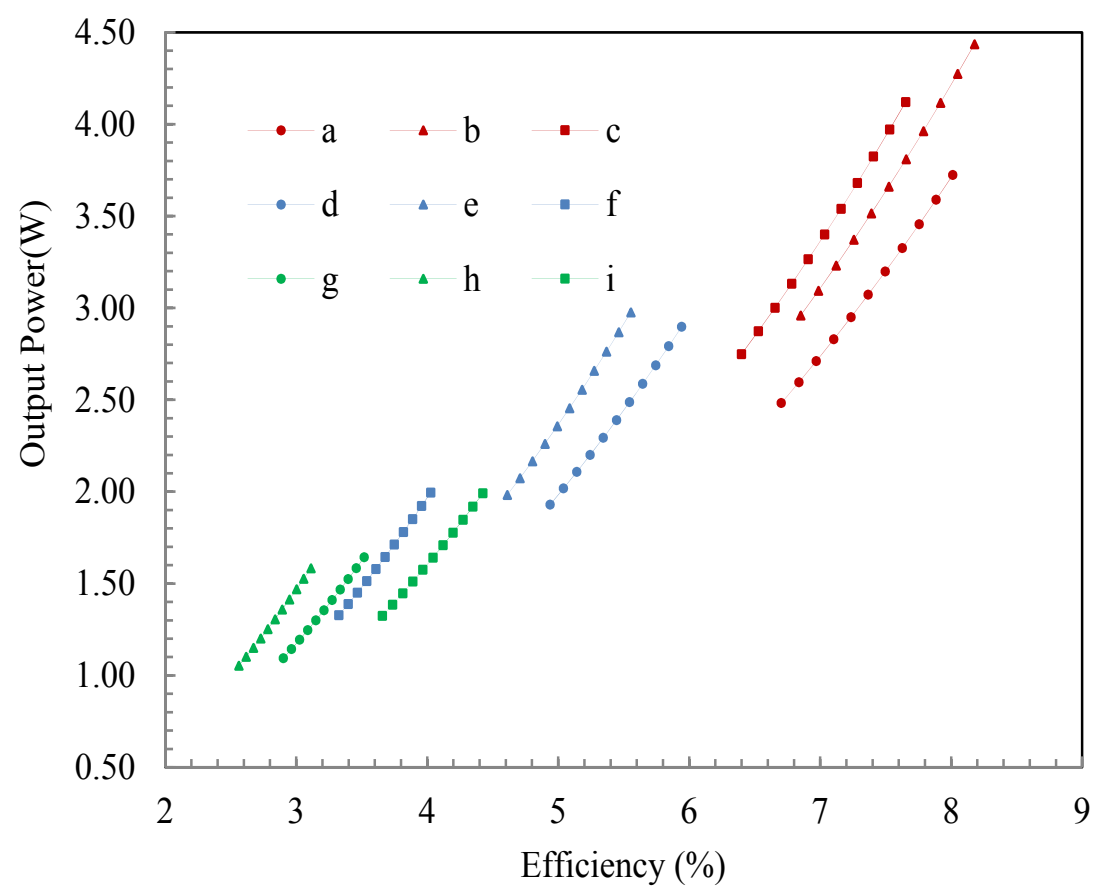

Figure 4: Variation of output power at different efficiency of different TE materials $\left(\mathrm{a}=\mathrm{n}\right.$-type nano composite $\mathrm{Bi}_{2} \mathrm{Te}_{3}$ and p-type $(\mathrm{Bi}, \mathrm{Sb})_{2} \mathrm{Te}_{3}, \mathrm{~b}=$ n-type hot forged $\mathrm{Bi}_{2} \mathrm{Te}_{3}$ and $\mathrm{p}$-type $(\mathrm{Bi}, \mathrm{Sb})_{2} \mathrm{Te}_{3}$, $\mathrm{c}=$ n-type $\mathrm{Bi}_{2} \mathrm{Se}_{0.3} \mathrm{Te}_{2.7}+\mathrm{x}$ vol.\% $\gamma-\mathrm{Al}_{2} \mathrm{O}_{3}$ and $\mathrm{p}$-type $(\mathrm{Bi}, \mathrm{Sb})_{2} \mathrm{Te}_{3}$, $\mathrm{d}=$ n-type $(\mathrm{PbTe})_{0.88}(\mathrm{PbS})_{0.12}$ and p-type $0.03 \mathrm{~mol} \% \mathrm{PbI}_{2}, \mathrm{PbTe}$, $\mathrm{e}=$ n-type $\mathrm{PbTe}: \mathrm{La} / \mathrm{Ag}_{2} \mathrm{Te}$ and p-type $0.03 \mathrm{~mol} \% \mathrm{PbI}_{2}, \mathrm{PbTe}$, $\mathrm{f}=\mathrm{n}$-type La-doped $(\mathrm{PbTe})_{0.945}\left(\mathrm{Ag}_{2} \mathrm{Te}\right)_{0.055}$ and p-type 0.03 mol\% $\mathrm{PbI}_{2}, \quad \mathrm{PbTe}, \mathrm{g}=$ n-type La-doped $(\mathrm{PbTe})_{0.945}\left(\mathrm{Ag}_{2} \mathrm{Te}\right)_{0.055}$ and p-type $\mathrm{Ag}_{6.52} \mathrm{Sb}_{6.52} \mathrm{Ge}_{35.96} \mathrm{Te}_{50} \mathrm{Dy} 1, \mathrm{~h}=\mathrm{n}$-type La-doped $(\mathrm{PbTe})_{0.945}\left(\mathrm{Ag}_{2} \mathrm{Te}\right)_{0.055}$ and p-type $\mathrm{Ag}_{6.52} \mathrm{Sb}_{6.52} \mathrm{Ge}_{34.96} \mathrm{Te}_{50}$ Dy2, $\mathrm{i}=$ n-type La-doped $(\mathrm{PbTe})_{0.945}\left(\mathrm{Ag}_{2} \mathrm{Te}\right)_{0.055}$ and p-type TAGS-75).

Figure 5 illustrates the enhancement of total output power with number of modules for different materials. Here, TEG modules based on Bismuth telluride group material is generating maximum total output power around $23 \mathrm{~kW}$ from 5,200 modules while the modules based on other two group materials namely, Lead telluride and TAGS are generating $15.5 \mathrm{~kW}$ and $10.4 \mathrm{~kW}$ respectively from the same number of modules. 


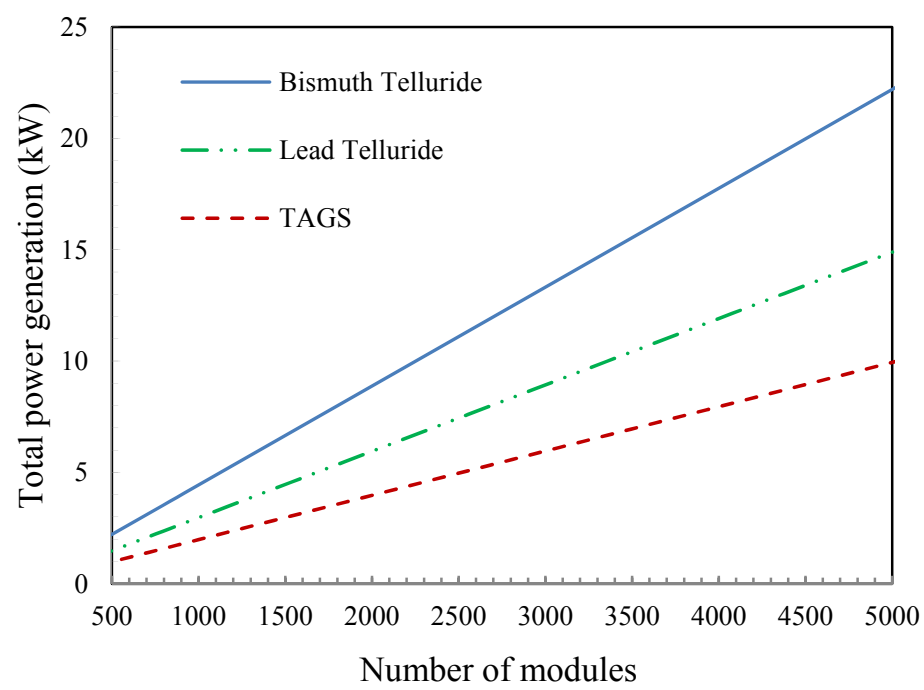

Figure 5: Variation of output power with the number of module of different TE materials.

\section{Conclusion}

Maximum power generation by applying TEG with plate fin heat sink is the main focus of this study. Materials from three different thermoelectric groups Bismuth telluride, Lead telluride and TAGs have been analysed as they are the best suited $\mathrm{TE}$ material for this temperature range. Among them p-type $(\mathrm{Bi}, \mathrm{Sb})_{2} \mathrm{Te}_{3}$ and n-type hot forged $\mathrm{Bi}_{2} \mathrm{Te}_{3}$ has been found to be the best material. The estimated annual output power is $181,209 \mathrm{kWh}$ by using p-type $(\mathrm{Bi}, \mathrm{Sb})_{2} \mathrm{Te}_{3}$ and n-type hot forged $\mathrm{Bi}_{2} \mathrm{Te}_{3}$. Developing TE materials with better TE properties energy can be recovered more efficiently in future.

\section{Acknowledgement}

This research is supported by High Impact Research MoE Grant UM.C/625/1/HIR/MoE/ENG /40 from the ministry of education Malaysia.

\section{References}

[1] Riffat, S.B. and X. Ma, Thermoelectrics: a review of present and potential applications. Applied Thermal Engineering, 2003. 23(8): pp. 913-935.

[2] Jang, J.-Y., Y.-C. Tsai, and C.-W. Wu, A study of 3-D numerical simulation and comparison with experimental results on turbulent flow of venting flue 
gas using thermoelectric generator modules and plate fin heat sink. Energy, 2013. 53: pp. 270-281.

[3] Ohta, H., K. Sugiura, and K. Koumoto, Recent Progress in Oxide Thermoelectric Materials: p-Type Ca3Co4O9 and n-Type SrTiO3-. Inorganic chemistry, 2008. 47(19): pp. 8429-8436.

[4] Hsiao, Y.Y., W.C. Chang, and S.L. Chen, A mathematic model of thermoelectric module with applications on waste heat recovery from automobile engine. Energy, 2010. 35(3): pp. 1447-1454.

[5] Hsu, C.-T., et al., Renewable energy of waste heat recovery system for automobiles. Journal of Renewable and Sustainable Energy, 2010. 2(1): p. 13-105.

[6] Ikoma, K., et al., Thermoelectric generator for gasoline engine vehicles using Bi2Te3 modules. J. Japan Inst. Metals. Special Issue on Thermoelectric Energy Conversion Materials, 1999. 63(11): pp. 1475-1478.

[7] Schlichting, A.D., S.R. Anton, and D.J. Inman. Motorcycle waste heat energy harvesting. in The 15th International Symposium on: Smart Structures and Materials \& Nondestructive Evaluation and Health Monitoring. 2008. International Society for Optics and Photonics.

[8] Takanose, E. and H. Tamakoshi. The development of thermoelectric generator for passenger car. in Proc. 12th International Conference on Thermoelectrics. Yokohama, Japan. 1993.

[9] Brazdil, M. and J. Pospisil, Thermoelectric Power Generation Utilizing the Waste Heat from a Biomass Boiler. Journal of electronic materials, 2013. 42(7): pp. 2198-2202.

[10] Moser, W., et al. Small-scale pellet boiler with thermoelectric generator. in Thermoelectrics, 2006. ICT'06. 25th International Conference on. 2006. IEEE.

[11] Kristiansen, N., et al., Waste heat recovery from a marine waste incinerator using a thermoelectric generator. Journal of electronic materials, 2012. 41(6): pp. 1024-1029.

[12] Champier, D., et al., Thermoelectric power generation from biomass cook stoves. Energy, 2010. 35(2): pp. 935-942.

[13] Rowe, D., A high performance solar powered thermoelectric generator. Applied Energy, 1981. 8(4): pp. 269-273.

[14] Zhao, X.B., et al., Bismuth telluride nanotubes and the effects on the thermoelectric properties of nanotube-containing nanocomposites. Applied Physics Letters, 2005. 86(6): pp. 62-111.

[15] Cao, Y.Q., et al., Syntheses and thermoelectric properties of $\mathrm{Bi}_{2} \mathrm{Te}_{3} / \mathrm{Sb}_{2} \mathrm{Te}_{3}$ bulk nanocomposites with laminated nanostructure. Applied Physics Letters, 2008. 92(14): pp. 14-3106.

[16] Zhao, L.D., et al., Enhanced thermoelectric and mechanical properties in textured n-type Bi2Te3 prepared by spark plasma sintering. Solid State Sciences, 2008. 10(5): pp. 651-658.

[17] Li, F., et al., Enhanced thermoelectric properties of n-type Bi2Te3-based nanocomposite fabricated by spark plasma sintering. Journal of Alloys and Compounds, 2011. 509(14): pp. 4769-4773. 
[18] Gelbstein, Y., Z. Dashevsky, and M.P. Dariel, High performance n-type PbTe-based materials for thermoelectric applications. Physica B: Condensed Matter, 2005. 363(1-4): pp. 196-205.

[19] Li, X.X., et al., Enhanced thermoelectric properties of (PbTe) $0.88(\mathrm{PbS}) 0.12$ composites by Bi doping. Journal of Alloys and Compounds, 2013. 547: pp. 86-90.

[20] Pei, Y., et al., High Thermoelectric Performance in PbTe Due to Large Nanoscale Ag2Te Precipitates and La Doping. Advanced Functional Materials, 2011. 21(2): pp. 241-249.

[21] Levin, E.M., S.L. Bud'ko, and K. Schmidt-Rohr, Enhancement of Thermopower of TAGS-85 High-Performance Thermoelectric Material by Doping with the Rare Earth Dy. Advanced Functional Materials, 2012. 22(13): pp. 2766-2774.

[22] Schröder, T., et al., TAGS-related indium compounds and their thermoelectric properties - the solid solution series (GeTe)xAgInySb1 $-y \operatorname{Te} 2(x=1-12 ; y=0.5$ and 1$)$. Journal of Materials Chemistry A, 2014. 2(18): p. 6384.

[23] MA Guang-yua, b., CAI Jiu-jua, ZENG Wen-weia, DONG Huia, a, Analytical Research on Waste Heat Recovery and Utilization of China's Iron \& Steel Industry. 